УДК 811.163.41'282

DOI: https://doi.org/10.18485/kij.2016.63.3_4.9

\begin{abstract}
Филозофски факултет
Универзитет у Нишу
\end{abstract}

АЛЕКСАНДАР М. НОВАКОВИЋ
Оригинални научни рад

Примљен: 20. 11. 2016.

Прихваћен: 21. 12. 2016.

\title{
ХИПЕРКОРЕКЦИЈА У ГОВОРУ УЧЕНИКА И СТУДЕНАТА НА ПОДРУЧЈУ ПРИЗРЕНСКО-ТИМОЧКОГ ДИЈАЛЕКТА
}

\begin{abstract}
Рад се бави истраживањем појаве хиперкорекције у говору ученика основних и средњих школа, као и студената нефилолошких факултета на подручју призренско-тимочког дијалекта. Истраживање спроведено у децембру 2015. године у потпуности је потврдило почетну хипотезу да ће склоност ка хиперкорекцији расти идући ка вишим нивоима образовања у складу са променом броја часова српског језика које ученици и студенти имају у својим школама и факултетима. Веза између стадијума образовања и хиперкорекције утврђена је уз помоћ програмског пакета SPSS 20.0. На узорку од 305 испитаника највећу склоност ка хиперкоркориговању показали су студенти IV године нефилолошких факултета, нешто мању ученици IV разреда гимназије, а најмању ученици VIII разреда основне школе. Процентуално изражено, 90,1\% студената, 79,8\% средњошколаца и $71 \%$ основношколаца начинило је неку врсту хиперкорекције.

Кључне речи: хиперкорекција, призренско-тимочки дијалекат, настава српског језика, језичка несигурност, престиж у језику.
\end{abstract}

Најбољи наставници српског језика су они који се труде да помире дијалекат и кьижевни језик повезујући их у нераздвојну целину, у којој сваки од юих има своје место и значај.

(Јањић 2004: 423)

\section{1. Увод}

Хиперкорекција се може дефинисати као погрешна употреба престижне језичке јединице до које долази када тражени варијетет није добро познат особи која га употребљава (Традџил 2003: 59-60). Уколико би се сликовито покуша-

*aleksandar.novakovic@filfak.ni.ac.rs 
ла објаснити појава хиперкорекције, то би се могло учинити на следећи начин. Нека постоји претпоставка да особа А говори језичким варијететом који је близак стандарду једног језика (на пример, шумадијско-војвођанским дијалектом), а особа Б говори језичким варијететом који је удаљен од стандарда (на пример, призренско-тимочким дијалектом); особа Б уочава да особа А користи локативну форму у Франиуској (Био сам у Франиуској). Како особа Б осећа да у своме дијалекту нема локативне (за њега престижне) форме, покушава да је употреби, али у погрешном контексту, притом правећи грешку: *Идем у Франиуској, уместо Идем у Франиуску.

Питање хиперкорекције привлачи лингвисте безмало већ пола века. Прошло је тачно педесет година откада је Вилијам Лабов публиковао своју прву социолингвистичку студију (видети Лабов 1966). У њој је дефинисао појам хиперкорекиије као важног термина у социолингвистици, до кога је дошао анализирајући говорне обрасце Њујорчана. Кренувши од претпоставке да ће виши социјалноекономски слојеви друштва у већој мери користити стандардне форме од социјалноекономских група које се налазе директно испод њих, Лабов је пронашао одступање од овог, редовног обрасца - нижа средња класа прелази у средњу класу по учесталости коришћења стандардне или престижне варијанте језика. Тако, нижа средња класа врши хиперкорекцију, односно хиперкоригује, што не одговара очекиваном обрасцу да нижа средња класа мање користи стандардне (престижне) облике језика.

Ричард Јанда (1978) сматра да хиперкорекција настаје онда када говорник нижепрестижног дијалекта греши у употреби облика страног том дијалекту, односно користи облик који је позајмљен из дијалекта са вишим престижом, тј. оног који је ближи стандарду. Социолингвистички, хиперкорекција постоји у два облика:

1. hypercorrect-ion - коришћење престижне форме од стране говорника дијалекта са нижим престижом, и

2. hyper-correction (хипер-исправка) - уобичајенија форма у којој постоји претерана употреба процеса исправљања другачије, „погрешне”, мање престижне форме (Јанда 1978: 1).

За Лабовљевим и Јандиним истраживањима уследила су истраживања Р. Марија (1996), Р. Бласта (1983), П. Традџила (2003) и, код нас, Б. Станковића (2016). Анализом истраживања у којима су се аутори бавили феноменом хиперкорекције може се извући закључак да се пажња посвећује социолошким, психолошким и фонетским факторима који утичу на њену појаву, што је и разумљиво с обзиром на то да је реч о социолингвистичком термину. Међутим, ако се мало боље размисли, тиме се не искључују узрочници који доводе до њене појаве. Између осталих, као најважнији истиче се (не)извођење наставе језика (у нашем случају, наставе српског језика). Стога се у овом раду истражује корелација између појаве хиперкорекције и наставе српског језика. У истраживање се кренуло од хипотезе да ће склоност ка хиперкорекцији расти идући ка вишим 
нивоима образовања у складу са променом броја часова српског језика. Ако би се хипотеза поједноставила, то би практично значило да ће ученици осмог разреда, који редовно похађају часове српског језика, много мање хиперкориговати од својих другова који завршавају четврти разред средње школе, у коме је веома мало часова посвећено настави српског језика, а који ће ипак имати далеко мање склоности ка хиперкорекцији од студената четврте године факултета на којима се не организује и не изводи настава српског језика.

Рад је организован према следећој композицији: други одељак се бави језичким престижом, те односом стандардног језика и дијалекта и језичком несигурношћу као узрочницима појаве хиперкорекције код говорника тог језичког варијетета; трећи део рада се бави методолошким поставкама спроведеног истраживања (предметом, значајем, хипотезом, методологијом и корпусом истраживања); четврти део доноси анализу добијених резултата, а пети део одређене закључке, након кога следи попис коришћене литературе.

\section{2. Престиж у језику}

У социолингвистици под престижом се подразумева ниво поштовања одређеног језика или дијалекта у односу на друге језике и дијалекте унутар одређене говорне заједнице. Престиж се обично уско везује за стандардизоване језичке варијетете. Уобичајено је да се стандардни језички варијетет изједначава са појмом највиши престижни варијетет. Ово изједначавање стандарда и престижа се везује за квантитативну социолингвистику (Милрој 2001: 532). Општепозната је чињеница да стандард ужива неоспорив престиж. ${ }^{1}$

Стандардни језик почива на избору једног дијалекта који ће бити основица књижевног језика. У случају српског књижевног језика то је шумадијско-војвођански дијалекат на екавској и источнохерцеговачки дијалекат на ијекавској територији (Богдановић, Марковић 2000: 12). Међутим, који ће дијалекат од мноштва који постоје у једном језику бити изабран за основицу зависи од више критеријума, између којих се посебно истичу ауторитет и престиж.

Неопходно је приметити да престиж није примарно својство језичког облика или варијанте - он је својство говорника, или групе говорника, од којих неки имају већи друштвени престиж од других што је очито повезано с разликама у друштвеној класи или друштвеном статусу. Дакле, престиж језичким варијантама додељују говорници, а то чине на основу поређења облика за које се сматра да су језички облици виших друштвених класа. Овде се опет ради о ауторитету: неке друштвене скупине имају већи ауторитет него друге. Чини се да оно што постаје стандард у једном језику одређују они чији приходи зависе од широко распрострањене комуникације, те релативни престиж таквих група може играти одређену улогу у одређивању онога што ће постати стандард.

\footnotetext{
${ }^{1}$ Термин престиж потиче о француске речи prestige, у значењу више цењени облик.
} 
Стандардни облик постаје легитиман, а остали облици, према раширеном веровању, постају нелегитимни, тј. супстандардни облици. То утиче на то да једни облици буду облици друштвеног престижа, са једне стране, док се негативно одражава на статус нестандардних језичких варијетета, који у тој констелацији губе на угледу, са друге стране (Гарет и сар. 2011: 61).

\section{1. Однос (призренско-тимочког) дијалекта и стандардног говора као узрок појаве хиперкорекције}

Познато је да је српски језик дијалекатски јако рашчлањен. У њему однос између дијалеката и стандардног језика почива на принципу језичке интерференције, односно међусобног преплитања; схвата се као живи организам у коме су сви његови елементи у узајамном додиру и саживоту. Другим речима, дијалекти утичу на мењање стандардног језика и обрнуто. Никако се не сме заборавити чињеница да је стандардни језик друштвено изгласан и прихваћен дијалекат (Богдановић, Марковић 2000: 12).

Узроци стандардизације говора, а уједно и услови у којима се она одвија, јесу урбанизација, обавезна основна школа, средства масовног јавног општења, као и ставови који постоје код нас о дијалекту и употреби дијалекта, односно о стандарду и употреби стандарда (Рајић 1981: 244). Са развојем стандардног језика, расте и појава диглосије као лингвистичког термина. Наиме, припадници дијалекатског језичког подручја, када се нађу у матичној средини, користе се дијалектом у општењу са припадницима истог дијалекта. Међутим, када се нађу међу припадницима стандардне језичке варијанте, улажу напоре како би се што правилније служили стандардним језиком. У том смислу долази до (не)свесне идентификације са новом средином (говорници сматрају да су се прилагодили и постали „грађани”) са свесном тежњом за диференцијацијом у односу на стару средину (сматра се да се на тај начин побољшава социјални статус). На тој разини и настају најпогоднији услови за појаву хиперкорекције, као социолингвистичког феномена, те престиж постаје извор забуне, односно језичке несигурности (Милрој 2001: 533).

Нашавши се у новој средини, међу новом популацијом² ${ }^{2}$ до тада говорници дијалекатског подручја покушавају да усвоје и примене правила која су учили у школи, погрешно их употребљавајући и прегенерализујући. Анализом категорија јасно се уочава да до појаве хиперкориговања долази приликом употребе језичких јединица несвојствених дијалекатским говорницима у погрешним контекстима; до хиперкорекције долази у оним граматичким категоријама које постоје у стандардном језику, али не и у дијалектима. Управо из горенаведених разлога, призренско-тимочки дијалекат представља погодно подручје за наста-

\footnotetext{
${ }^{2}$ Као објективни маркер идентитета, као медијум за исказивање и афирмисање идентитета, језик је од суштинског значаја за преношење и очување симбола, вредности, уверења и свих оних елемената који чине да једну културу, етничку групу или нацију осећамо као своју (Пауновић, Лопичић 2008: 365-383).
} 
нак хиперкорекције ${ }^{3}$. Као што је речено, хиперкорекција се сматра, пре свега, социолингвистичком појавом. Језичко (у овом случају дијалекатско) питање као индикатор идентитета сматра се важним фактором који утиче на начин размишљања његових говорника (Карли и сар. 2003: 868). Низ одлика по којима се призренско-тимочки дијалекат разликује од стандардног говора српскога језика узрок је који доводи до појаве склоности хиперкориговања код припадника овог језичког подручја. Знајући (или препознајући) низ особина које карактеришу стандардни језички варијетет, а које сами говорници призренско-тимочких говора немају, у жељи да се приближе престижном говору, чине употребу истих у погрешним језичким контекстима, што доводи до настанка хиперкорекције.

Веза између начина говора и друштвене стратификације одавно је предмет проучавања у социолингвистици - већ су поменути пионирски радови Вилијама Лабова (Лабов 1963, 1966, 1972). Она до данас остаје једно од кључних питања социолингвистике. У случају ,јужњачких дијалеката” и њихових говорника, ради се, међутим, о сасвим другачијем процесу: овде је класна припадност замењена територијалном. Становници читавог једног подручја се на основу дијалекта, дакле територијално, смештају у одређене социјалне и културне категорије. Осећајући такав став према своме дијалекту, говорници покушавају да се издигну из њега, да га оставе иза себе; међутим, у томе не успевају, показујући склоност ка хиперкорекцији. У српском језику хиперкорекција се јавља: приликом огрешења о правилну дистрибуцију фонеме/фонемског низа у одређеном контексту; приликом акцентовања речи у српском језику; у употреби погрешног облика именице у паукалним синтагмама; приликом погрешне конгруенције у конструкцијама придев + број + именица; у неразликовању локомоције од локације; у непримереној употреби аориста помоћног глагола бити при грађењу потенцијала; у појави гласа $x$ у речима у којима га према етимологији нема; коришћењем речи људи уместо речи човек(a) за означавање броја особа мањег од пет; уопштавањем сугласника $m$ у придевима мушког рода; приликом уопштавања сугласника -в- у појединим речима; прегенерализацијом правила о чувању сугласника -л у речима.

\section{2. Језичка несигурност као извор хиперкорекције}

Термин лингвистичка несигурност односи се на осећање анксиозности и недостатка самопоуздања у коришћењу језика од стране његових говорника. ${ }^{4}$

\footnotetext{
${ }^{3}$ Другачији развојни пут од осталих штокавских говора утицао је да призренско-тимочки говори имају низ особина које их разликују од шумадијско-војвођанских, узетих за основицу српског стандардног језика - губљење квантитативних опозиција у прозодији и свођење на један (експираторни) акценат, упрошћавање система деклинације и свођење на два облика (номинатив и општи падеж), аналитичко поређење придева, губљење инфинитива и његова замена конструкцијом да + презент, удвајање облика личних заменица и појава члана (у одређеним говорима призренско-тимочке зоне) (Богдановић, Марковић 2000: 150-152).

${ }^{4}$ Терминологија се везује за истраживања америчког социолингвисте Вилијама Лабова (1972: 4) који је проучавајући језичке заједнице у Њујорку дефинисао лингвистичку несигурност као
} 
Често ова анксиозност потиче из веровања да његова употреба није у складу са стандардом језика или стила који се очекује од говорника. Стандардна форма језика је кодификована форма која се користи у јавном дискурсу, при чему она представља престижну форму језичког варијетета. Варијабле које стандардну форму разликују од нестандардне форме односе се пре свега на фонетску реализацију, вокабулар, синтаксу и многе друге чиниоце језика. У вези са тим, употреба стандардне форме језика често је извор лингвистичке несигурности код говорника једног језика. Она се најбоље испољава у ситуацијама када лингвистички несигурни говорници врше промене њиховог свакодневног говора која није ништа друго него одраз њихове несигурности.

Језичка несигурност се ситуационо индукује и често је резултат осећања неадекватности у вези са личним учинком у одређеним контекстима. Несигурност може довести до стилских, фонетских, морфолошких и синтаксичких промена и може бити одраз свесне промене или несвесног прилагођавања стандардном језику.

Истраживања показују да су поједина језичка подручја погоднија за стварање климе лингвистичке несигурности. Наиме, то су пре свега вишедијалекатска и вишејезична подручја. Вилма Буци и Милтон Бакстер у своме раду Проблеми лингвистичке несигурности у мултикултуралним говорним контекстима истичу да се степен језичке несигурности повећава у језичким подручјима у којима више дијалеката егзистира у стандардном језику. Несигурни говорници пате од осећаја ниже вредности који им стварају говорници стандардног језичког варијетета, те често осећају притисак да маскирају свој дијалекат приближавајући га стандардној форми језика. Дводијалекатски говорници, који се користе обема варијантама језика, и стандардном и дијалекатском, најугроженији су у овом проблему зато што су свесни језичких норми и контекста којем морају да прилагоде свој говор. За монодијалекатске говорнике, конверзација може бити тешка или стресна зато што су закључани у свој нестандардни дијалекат и знатно им је теже да га прилагоде стандардном дијалекту (Буци и Милтон 1984: 185-200).

У складу са претходно реченим, аутор овога рада је за подручје испитивања феномена хиперкорекције изабрао Ниш из разлога што овај град представља највећи центар призренско-тимочке дијалекатске зоне.

\section{3. Методологија истраживања}

Ово истраживање за предмет има појаву хиперкорекције код ученика основних и средњих школа, као и студената нефилолошких факултета. Природа посла којим се аутор овога рада бави ставља га у ситуацију да свакодневно дола-

осећање различите лигнвистичке перцепције. У новије време овим феноменом бавила се Невежина Јелисавета Андрејевна у своме раду $О$ језичкој несигурности где заправо пажњу ставља на феномен језичке несигурности у Бриселу и Валонији (Андрејевна 2012). 
зи у контакт са ученицима (основних и средњих школа) и студентима како филолошких, тако и нефилолошких факултета, те и неминовности уочавања појаве хиперкориговања током конверзације са поменутим групама.

Како се хиперкорекција сматра социолингвистичким термином, приликом истраживања се у обзир узима више параметара, као што су: старост, пол, социоекономски статус, етничка припадност, регистар ${ }^{5}$ и слично. Међутим, аутор примећује да до појаве хиперкорекције код ученика долази у ситуацијама када се ученици нађу пред статусно надређеним особама, односно професорима српског језика. Плашећи се да не направе грешку, ученици то и чине употребом оне језичке јединице коју не користе у свакодневном говору. ${ }^{6}$ У том светлу хиперкорекцију аутор рада посматра као вид лингвистичке несигурности, о чему је било речи у претходним поглављима ${ }^{7}$. Осим тога, поменути однос према јужнијим српским дијалектима, као и неквалитетно организована настава српског језика, такође су узрочници појаве хиперкорекције.

Наставна пракса показује да је предмет Српски језик (и књижевност) најзаступљенији у наставним програмима за основну школу, где се у највишим разредима (у осмом разреду) изучава четири пута недељно, док у нижим разредима чак пет пута недељно. Ситуација у средњим школама је другачија. Пре свега, у зависности од типа школе, али и повезаности наставе књижевности и језика, српски језик се изучава на много мањем броју часова, него што би то заиста било потребно. Иако је од велике важности за сваког појединца који је део друштвеног система, нема га међу курикулумима на студијским програмима нефилолошких факултета. Стога је предмет истраживања овог рада појава хиперкорекције у корелацији са (не)постојањем наставе српског језика.

Јасно се примећује да се лингвистичка несигурност код ученика повећава са њиховим удаљавањем од наставе српског језика. Првенствени значај овога рада огледа се у чињеници да се феноменом хиперкорекције у наставном контексту на просторима бивше Југославије досада истраживачи нису бавили. Резултати спроведеног истраживања треба да баце ново светло на сагледавање феномена хиперкорекције, али и да укажу на значај наставе српског језика за говорнике српског језичког подручја, посебно за ученике и студенте.

Шта више, резултати истраживања могу бити добар показатељ у ком смеру би требало да се креће реформа наставног система, односно требало би да покаже важност раздвајања наставе језика и књижевности у средњој школи, као

${ }^{5}$ Лингвистички регистар се односи на варијетет говора датог језика који кореспондира са ситуационо или социјално одређеним контекстом.

${ }^{6}$ Да је ова тврдња тачна, показује и ситуација у којој се аутор нашао на научном скупу Наука и савремени универзитет 5 у организацији Филозофског факултета у Нишу. Наиме, након што су у једној од сесија учесници завршили своја излагања, у времену које је предвиђено за дискусију о радовима, професорка руског језика која је присуствовала сесији јавно је изразила страх да учествује у коментарисању, јер, како каже, није студирала српски језик.

${ }^{7}$ Пажљивим слушањем својих студената и ученика у школама, аутор је дошао до закључка да до хиперкорекције готово уопште не долази када студенти (ученици) међу собом комуницирају, већ се служе својим дијалектом. 
и увођења наставе српског језика на нефилолошким факултетима. Повећањем фонда часова српског језика неминовно ће се утицати и на процентуално смањење појаве феномена хиперкорекције у говору ученика и студената.

На основу одређеног проблема, дефинисаног предмета и значаја истраживања, хипотеза гласи: Феномен хиперкорекиије је у блиској вези са извођењем наставе српског језика. Како се фонд часова српског језика сманује са повећањем нивоа иколовања, појава хиперкорекиије расте. Тако, најмањи процентуални удео у појави феномена хиперкорекиије имаће ученици осмог разреда, нешто већи ученици четврте године средње школе, док ће највећи проченат хиперкорекиије имати студенти четврте године нефилолошких факултета.

Када је у питању експериментална процедура, провера степена појаве феномена хиперкорекције међу ученицима и студентима врши се методом дескриптивне анализе и статистичке обраде података уз помоћ програма SPSS 20.0. У истраживању је коришћена техника анкетирања, а за главни инструмент одабран је упитник. Аутор је саставио три упитника - за основношколце, за средњошколце и студенте на нефилолошким факултетима - али уз напомену да су сва три упитника садржала иста питања на које је требало дати одговоре.

Упитник је анонимног карактера. Састојао се из два дела. На самом почетку првог упитника налази се краће упутство за попуњавање упитника, као и једанаест питања којим се жели проверити појава поменутог феномена. Пре сваког питања налази се јасно формулисан задатак. Други део упитника садржи питања за прикупљање информација о био-дати - подаци који су од важности за истраживача: школа (факултет), пол, место рођења, место сталног живљења, стручна спрема родитеља (старатеља), као и место рођења родитеља. Попуњавање упитника није временски ограничено, али због његове једноставности ученицима и студентима није било потребно више од петнаест минута.

Испитаници су, сходно почетној хипотези, били ученици осмог разреда основних школа Вожд Карађорђе и Радоје Домановић из Ниша, ученици гимназије 9. мaj, као и студенти четврте године нефилолошких факултета Универзитета у Нишу (Правни факултет, Факултет спорта и физичког васпитања, Електронски и Машински факултет). ${ }^{8}$ У истраживању је учествовало 305 испитаника (133 мушкарца и 172 жене): 100 основношколаца (41 дечак и 59 девојчица), 104 средњошколца (37 дечака и 67 девојчица) и 101 студент четврте године нефилолошких факултета (55 момака и 46 девојака). ${ }^{9}$

\footnotetext{
${ }^{8}$ Мора се нагласити да испитаници све три групе имају стално место живљења у граду.

${ }^{9}$ Сви испитаници су са подручја призренско-тимочке дијалекатске зоне.
} 
Табела 1. Приказ полне структуре испитаника према нивоу образовања

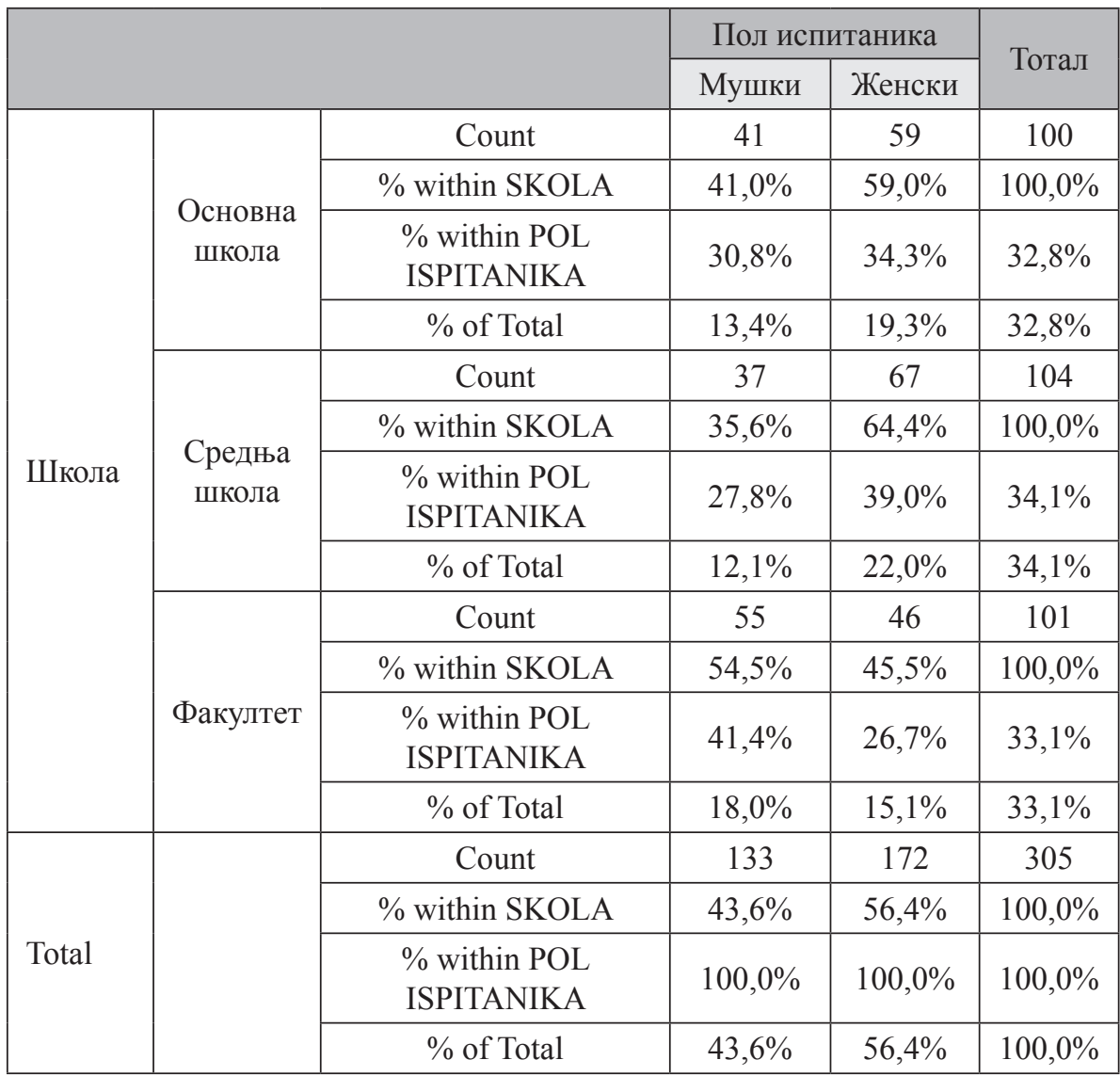

Анкетирано је укупно 305 испитаника - 100 ученика осмог разреда, 104 ученика четврте године гимназије, 101 студент нефилолошких факултета.

Добијени резултати су анализирани уз помоћ софтверског пакета SPSS 20.0 , уз помоћ кога је утврђен и степен корелације између наведених варијабли у хипотези. Пре него што се приступило дескриптивној анализи, сви подаци из упитника су кодирани и унети у поменути софтвер. Добијени резултати су представљени у наредном поглављу.

\section{4. Интерпретација резултата и истраживања}

Резултати истраживања су показали да је 245 испитаника (80,3\%) начинило хиперкорекцију одређеног типа, док само 60 испитаника (19,7\%) није хиперкориговало. 
Табела 2. Приказ броја ученика (студената) који су учинили хиперкорекиију

\begin{tabular}{|c|c|c|c|c|c|}
\hline \multicolumn{7}{|c|}{ Хиперкорекција } \\
\hline \multirow{2}{*}{ Valid } & Frequency & Percent & $\begin{array}{c}\text { Valid } \\
\text { Percent }\end{array}$ & $\begin{array}{c}\text { Cumulative } \\
\text { Percent }\end{array}$ \\
\hline & $\begin{array}{c}\text { Нема } \\
\text { хиперкорекције }\end{array}$ & 60 & 19,7 & 19,7 & 19,7 \\
\cline { 2 - 6 } & $\begin{array}{c}\text { Начињена } \\
\text { хиперкорекција }\end{array}$ & 245 & 80,3 & 80,3 & 100,0 \\
\cline { 2 - 6 } & Total & 305 & 100,0 & 100,0 & \\
\hline
\end{tabular}

Хипотеза да ће хиперкорекција расти са повећањем узраста (разреда) у потпуности је потврђена, јер су ученици осмог разреда основне школе 71 пут хиперкориговали, ученици четврте године (гимназије) 83 пута, а студенти чак 91 пут. Другим речима, 71\% испитаних основношколаца, 79,8\% средњошколаца и чак 90,1\% студената је хиперкориговао. Из ових података се јасно види да појава хиперкорекције расте са удаљавањем од наставе српског језика (видети графички приказ бр. 1). Као што је објашњено у претходним поглављима, са повећањем узраста, односно нивоа школовања, ученици (студенти) се све више удаљавају од наставе српског језика (број часова језика се смањује) и тиме постају подложни стварању осећања језичке несигурности и повећању склоности ка хиперкориговању.

\section{Графички приказ 1. Приказ склоности ка хиперкорекиији према нивоу образована}

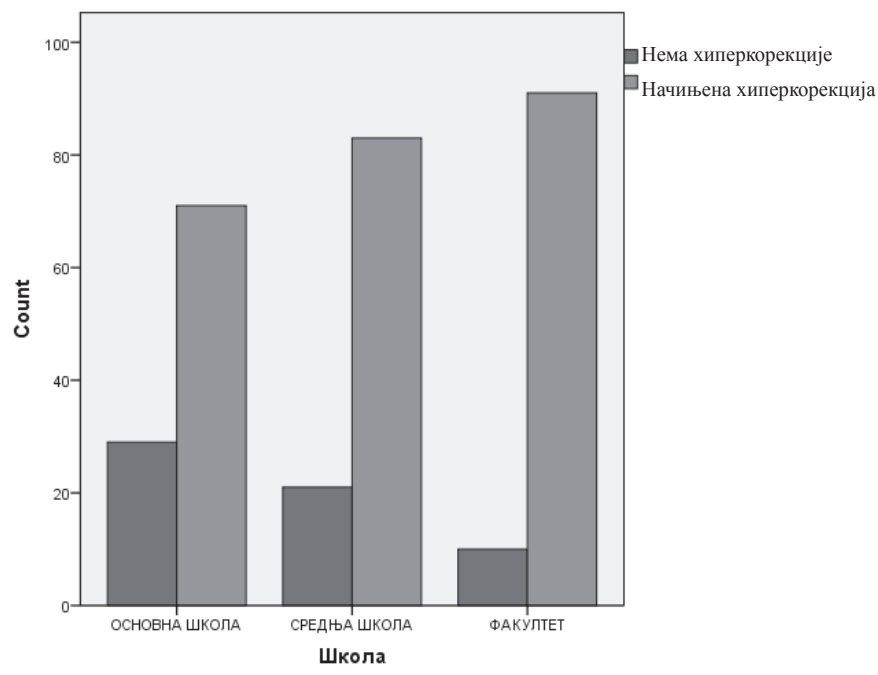


Табела 3. Приказ броја испитаника који су хиперкориговали према нивоу образовања

\begin{tabular}{|c|c|c|c|c|c|}
\hline \multicolumn{6}{|c|}{ ШКОЛА * ХИПЕРКОРЕКЦИЈА Crosstabulation } \\
\hline & & & \multicolumn{2}{|c|}{ ХИПЕРКОРЕКЦИЈА } & \multirow[b]{2}{*}{ Тотал } \\
\hline & & & $\begin{array}{c}\text { Нема } \\
\text { хиперкорекције }\end{array}$ & $\begin{array}{c}\text { Начињена } \\
\text { хиперкорекција }\end{array}$ & \\
\hline \multirow{12}{*}{ ШКОЛА } & \multirow{4}{*}{ Основна школа } & Count & 29 & 71 & 100 \\
\hline & & $\%$ within SKOLA & $29,0 \%$ & $71,0 \%$ & $100,0 \%$ \\
\hline & & $\begin{array}{l}\text { \% within } \\
\text { HIPERKOREKCIJA }\end{array}$ & $48,3 \%$ & $29,0 \%$ & $32,8 \%$ \\
\hline & & $\%$ of Total & $9,5 \%$ & $23,3 \%$ & $32,8 \%$ \\
\hline & \multirow{4}{*}{ Средња школа } & Count & 21 & 83 & 104 \\
\hline & & \% within SKOLA & $20,2 \%$ & $79,8 \%$ & $100,0 \%$ \\
\hline & & $\begin{array}{l}\text { \% within } \\
\text { HIPERKOREKCIJA }\end{array}$ & $35,0 \%$ & $33,9 \%$ & $34,1 \%$ \\
\hline & & $\%$ of Total & $6,9 \%$ & $27,2 \%$ & $34,1 \%$ \\
\hline & \multirow{4}{*}{ Факултет } & Count & 10 & 91 & 101 \\
\hline & & $\%$ within SKOLA & $9,9 \%$ & $90,1 \%$ & $100,0 \%$ \\
\hline & & $\begin{array}{l}\% \text { within } \\
\text { HIPERKOREKCIJA }\end{array}$ & $16,7 \%$ & $37,1 \%$ & $33,1 \%$ \\
\hline & & $\%$ of Total & $3,3 \%$ & $29,8 \%$ & $33,1 \%$ \\
\hline \multirow{4}{*}{\multicolumn{2}{|c|}{ Тотал }} & Count & 60 & 245 & 305 \\
\hline & & $\%$ within SKOLA & $19,7 \%$ & $80,3 \%$ & $100,0 \%$ \\
\hline & & $\begin{array}{l}\% \text { within } \\
\text { HIPERKOREKCIJA }\end{array}$ & $100,0 \%$ & $100,0 \%$ & $100,0 \%$ \\
\hline & & $\%$ of Total & $19,7 \%$ & $80,3 \%$ & $100,0 \%$ \\
\hline
\end{tabular}


Веза између нивоа образовања (школе), односно броја часова српског језика који су у периоду од четири године имали основношколци, средњошколци,

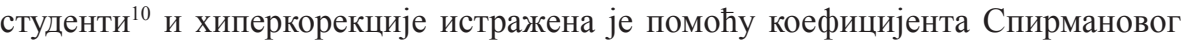
ранга корелације, који за редоследне величине препоручује ауторка књиге SPSS за преживљавање Џули Палант (Палант 2007: 71). Обављене прелиминарне анализе су показале да је корелација између хиперкорекције и школе (нивоа образовања) релативно слаба. Наиме, према Спирмановом коефицијенту ранга корелације на узорку од 305 испитаника јачина повезаности износи $\mathrm{r}_{\mathrm{s}=. .} .205$, што се сматра релативно слабом негативном корелацијом, уз велику сигурност да таква корелација постоји ( $<0.01)$. Негативна корелација упућује на чињеницу да је почетна хипотеза потврђена, јер се са смањењем броја часова српског језика повећава проценат учињене хиперкорекције.

Табела 4. Спирманов ранг коефииијанта корелације

\begin{tabular}{|c|c|c|c|c|}
\hline \multicolumn{5}{|c|}{ Correlations } \\
\hline & & & ШКОЛА1 & $\begin{array}{c}\text { ХИПЕР- } \\
\text { КОРЕКЦИЈА }\end{array}$ \\
\hline \multirow{6}{*}{$\begin{array}{l}\text { Spearman's } \\
\text { rho }\end{array}$} & \multirow{3}{*}{ ШКОЛА1 } & $\begin{array}{l}\text { Correlation } \\
\text { Coefficient }\end{array}$ & 1,000 &,$- 205^{* *}$ \\
\hline & & Sig. (2-tailed) & . &, 000 \\
\hline & & $\mathrm{N}$ & 305 & 305 \\
\hline & \multirow{3}{*}{$\begin{array}{l}\text { ХИПЕР- } \\
\text { КОРЕКЦИЈА }\end{array}$} & $\begin{array}{l}\text { Correlation } \\
\text { Coefficient }\end{array}$ &,$- 205^{* *}$ & 1,000 \\
\hline & & Sig. (2-tailed) & ,000 & . \\
\hline & & $\mathrm{N}$ & 305 & 305 \\
\hline
\end{tabular}

Уколико би се анализа окренула према оценама које су испитаници имали из српског језика током школовања, могло би се уочити да преовладавају петице и четворке. ${ }^{11}$ Тако је од 305 испитаника чак 188 навело да има (или је имало)

${ }^{10}$ Анализом наставних планова и програма утврђено је да су у периоду од четири године основношколци имали 17 часова на недељном нивоу (у просеку 4,25 по недељи), средњошколци 16 часова (или 4 часа у просеку) и студенти ниједан час српскога језика. Притом, под наставом српског језика подразумевали су се и часови књижевности, јер су три подручја (језик, књижевност, култура изражавања) неодвојива једно од другог.

${ }^{11}$ Разлог томе да преовладавају петице и четворке јесте тај што су испитивани ученици гимназије (као представници средњошколске популације) коју уписују или одлични или врло добри ученици, са просечном оценом већом од 4 . 
петицу из српског језика; 90 их је навело да има или је имало четворку; 26 је истакло да има или је имало тројку; и само један ученик је навео да има двојку. Занимљиво је то да су највише склоности ка хиперкориговању показали ученици који имају оцене три и четири - $100 \%$ тројкаша и $94,4 \%$ четворкаша је начинило неку врсту хиперкорекције.

Ако се погледа графички приказ бр. 2, уочава се интересантна појава. Beћу склоност ка хиперкорекцији особе женског пола показују у средњој школи, док особе мушког пола такву склоност показују тек на факултету.

Графички приказ 2. Однос хиперкорекције према полу и нивоу образовања

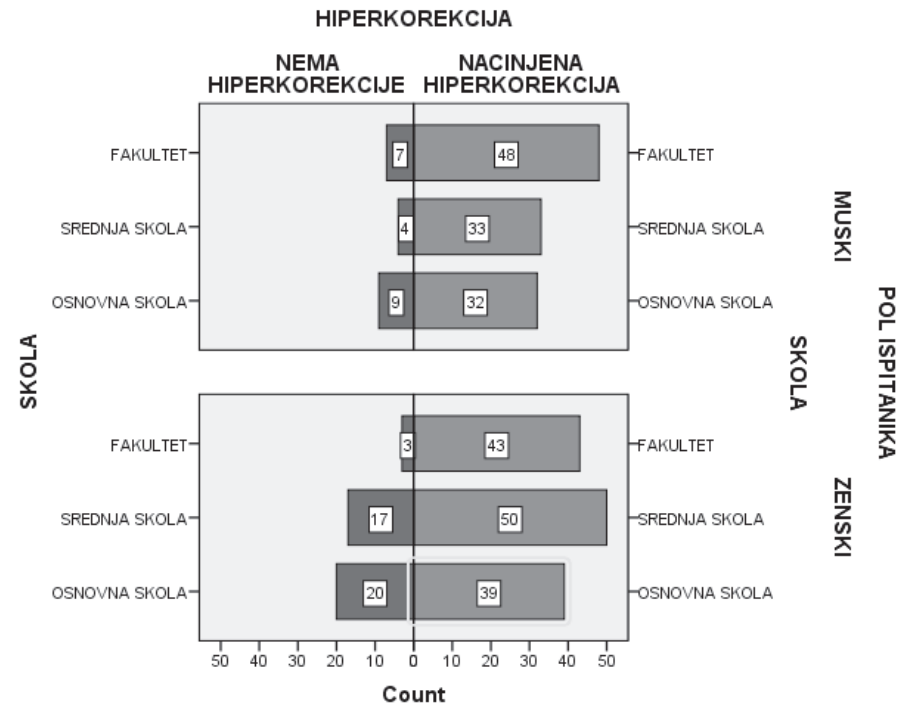

За аутора овога рада од велике важности јесте везивање хиперкорекције за појединачна питања. Захваљујући статистичкој анализи у програму SPSS 20.0 јасно се види на којим питањима су ученици (студенти) највише хиперкориговали. Ради прегледности и лакшег сналажења у табели која следи аутор даје детаљан увид у наведено стање. 
Табела 5. Приказ броја испитаника који су хиперкориговали према питањима

\begin{tabular}{|l|c|c|c|c|c|c|}
\hline \multirow{2}{*}{} & \multicolumn{2}{|c|}{$\begin{array}{c}\text { Основна } \\
\text { школа }\end{array}$} & \multicolumn{2}{c|}{$\begin{array}{c}\text { Средња } \\
\text { школа }\end{array}$} & \multicolumn{2}{c|}{ Факултет } \\
\cline { 2 - 7 } & ИХ & НХ & ИХ & НХ & ИХ & НХ \\
\hline 1. питање & $\mathbf{2 3}$ & 77 & $\mathbf{1 5}$ & 89 & $\mathbf{2 1}$ & 80 \\
\hline 2. питање & 2 & 98 & 3 & 101 & 3 & 98 \\
\hline 3. питање & 4 & 96 & $\mathbf{1 9}$ & 85 & $\mathbf{2 1}$ & 80 \\
\hline 4. питање & 0 & 100 & 0 & 104 & 0 & 101 \\
\hline 5. питање & 0 & 100 & 3 & 101 & 1 & 100 \\
\hline 6. питање & $\mathbf{1 7}$ & 83 & $\mathbf{3 1}$ & 73 & $\mathbf{4 5}$ & 56 \\
\hline 7. питање & $\mathbf{2 6}$ & 74 & 7 & 97 & $\mathbf{1 3}$ & 88 \\
\hline 8. питање & 1 & 99 & 0 & 104 & 0 & 101 \\
\hline 9. питање & $\mathbf{2 5}$ & 75 & $\mathbf{3 9}$ & 65 & $\mathbf{2 7}$ & 74 \\
\hline 10. питање & 0 & 100 & 0 & 104 & 2 & 99 \\
\hline 11. питање & $\mathbf{2 6}$ & 74 & $\mathbf{2 2}$ & 82 & $\mathbf{3 3}$ & 68 \\
\hline
\end{tabular}

Из табеле се јасно уочава да све три посматране групе (основношколци,

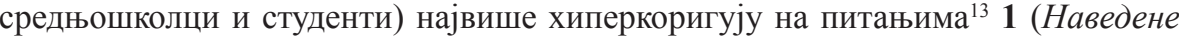
износе у динарима напишите словима - питање се односи на одговарајући облик именице хиљада), 6 (На основу географске карте Србије на тражена места упишите имена градова који се спомиьу - односи се на употребу одговарајућег падежа именице), 7 (Следећа реченица је неправилно написана. Препиши је да буде у складу са правописним и граматичким правилима српског језика - питање се такође односи на избор одговарајућег падежа, али овог пута придева који стоји уз број и именицу), 9 (На слици $A$ има пет људи. Колико их је на слици Б? - уписати одговарајући облик именице човек) и 11 (Колико животиға сваке врсте има на свакој од датих слика? - питање се односи на слагање у паукалним синтагмама). Свих пет питања припадају домену морфосинтаксе. Ако бисмо наведену појаву повезали са наставом српскога језика, очито је да наставници српскога језика нису остварили све циљеве наставе овог предмета, међу којима се истичу они који се односе на усвајање знања из области мор-

\footnotetext{
${ }^{12}$ Ради прегледности у овој табели се користе скраћенице: ИХ - има хиперкорекиије, односно НХ - нема хиперкорекције.

${ }^{13}$ Ради добијања упитника који је коришћен при истраживању, обратити се аутору рада.
} 
фологије и синтаксе, као и трајних знања, вештина и навика. Још један узрок оваквоме стању би се могао издвојити. Наиме, Милија Николић у својој Методиии наставе српског језика и књижевности истиче да се настава језика мора засновати на битним својствима и стилским функцијама језичких појава, као и на уважавању ситуационе условљености истих (Николић 1999: 635). Наведено се не може остварити без поштовања и посматрања контекста у коме се језичке појаве испољавају. Марина Јањић у своме раду Настава падежа у школама на подручју призренско-тимочког дијалекта истиче важност чињенице да настава (падежа) не сме бити изолована од осталих граматичких садржаја и наставних предмета, а не сме се одвијати ни ван друштвеног, психолошког и лингвистичког контекста ученика (Јањић 2004: 410). Са друге стране, наставна пракса нам показује сасвим другачију ситуацију - наставници у својим одељењима језичке појаве изучавају на појединачним примерима и реченицама извученим из контекста. Ако прихватимо Лабовљеву дефиницију хиперкорекције као употребе престижног лингвистичког обележја у погрешним контекстима, дефинитивно се као један од фактора који утичу на појаву хиперкорекције издваја настава српског језика и погрешан рад предметних наставника, који нису успели да ученицима језичке појаве представе у оним ситуацијама у којима се заиста појављују и за које се везују.

Осим реченог, још један податак се може извући посматрањем и анализом горе дате табеле. Удаљавањем од основношколске наставе и учења српског језика и његових правила најмање четири пута недељно, међу средњошколском и студентском популацијом примећена је повећана склоност ка хиперкориговању на питању број 3, односно питању које се тиче употребе правилног облика именице настале од глагола (не) зависити. Разлог је више него очигледан. У основној школи се ученици готово свакодневно подсећају од стране наставника на правилну употребу појединих облика речи. Међутим, како се број часова српскога језика смањује у средњој школи, а затим и нестаје на нефилолошким факултетима, потпуно је разумљиво да ученици постепено заборављају научена правила, те осећају језичку несигурност која се испољава кроз појаву хиперкорекције. Уз то се мора напоменути да је реч о дијалекатском подручју које је најудаљеније од стандардног језичког варијетета и које нема оне одлике и категорије карактеристичне за стандардни језички облик, те говорници (у овом случају ученици и студенти) знајући за такав однос између стандардног српског језика и призренског-тимочког дијалекта, осећају више несигурности него њихови вршњаци из других дијалекатских подручја, што резултује појавом хиперкорекције.

\section{5. Закључак}

Рад се бави корелацијом између настанка хиперкорекције и наставе српског језика. Посебна пажња је стављена на схватање термина хиперкорекција. Аутор је пошао од пионирских схватања хиперкорекције Вилијама Лабова, који ју је 
видео као примену престижног лингвистичког обележја у погрешним контекстима. За овим истраживачем уследила су истраживања Ричарда Јанде, Роберта Бласта, Роберта Марија, Давида Декампа, Традџила и, код нас, Бранимира Станковића, чије се дефиниције хиперкорекције делимично слажу, али у нечему и разликују. Једно је ипак сигурно - ниједан од ових аутора се није бавио хиперкорекцијом у говору ученика и настави (српског) језика.

У истраживање се кренуло од хипотезе да ће склоност ка хиперкорекцији расти идући ка вишим нивоима образовања у складу са променом броја часова српског језика. Спроведено истраживање је у потпуности потврдило почетну хипотезу. На узорку од 305 испитаника највећу склоност ка хиперкоркориговању су показали студенти IV године нефилолошких факултета, нешто мању ученици IV разреда гимназије, а најмању ученици VIII разреда основне школе. Процентуално изражено, 90,1\% студената, 79,8\% средњошколаца и $71 \%$ основношколаца је начинило неку врсту хиперкорекције.

Аутор је, поред добро познатих узрочника који доводе до хиперкорекције (престиж, осећање ниже вредности, пол), издвојио још један - неадекватно организовану и погрешно извођену наставу српског језика. Утврђено је постојање корелације између појаве хиперкорекције и наставе, што је потврђено израчунавањем Спирмановог ранга коефицијента корелације. Посебна пажња је усмерена на лоше примере у наставној пракси. Познато је да наставници српскога језика језичке појаве најчешће изучавају на појединачним примерима и реченицама истргнутим из контекста, што није у складу са оним што заговара Милија Николић у вези са извођењем наставе српског језика. У том смислу, ако се хиперкорекција схвати као употреба престижног лингвистичког правила у погрешним контекстима, постаје јасно зашто до ње и долази у говору ученика (и студената).

У раду је идентификован још један узрок настанка хиперкорекције - пропуст наставника српског језика да деци у школама објасне разлику између стандарда и дијалекта, због чије употребе ученици почињу стварати осећање ниже вредности; такво осећање покушавају надоместити коришћењем престижних граматичких правила, која често на часовима српског језика нису најбоље разумела. Од изузетне важности је ученике научити да прихватају друге без обзира на дијалекатске, националне, верске, родне и сличне разлике. Само такав ученик ће заузети правилан став према односу стандардног језика и дијалекта.

Елиминацијом локалног говора из наставног процеса, у главама ученика може доћи до психолошке баријере између стандарда и локалног говора (Јањић 2004: 410), која ће резултовати појавом хиперкорекције. Коришћење иманентне граматике у савладавању стандарднојезичке норме сигурно ће дати своје резултате и предупредити настанак хиперкорекције у говору ученика (и студената). Успостављањем разлике између иманентне и нормативне граматике и избором метода и методичких поступака, наставник и ученици ће бити на правом путу да остваре своје циљеве. 


\section{ЛИТЕРАТУРА}

Андрејевна 2008: N. E. Andreevna, About the Linguistic Security / Insecurity Phenomenon in Brussels and Wallonia, u: Russian Linguistic Bulletin, http://cyberleninka.ru. Приступљено: 5. 1. 2015.

Бласт 1983: R. Blust, A note on hypercorrection in Mongondow, u: Bijdragen tot de Taal-, Land- en Volkenkunde 139, no: 4, Leiden, 459-464.

Богдановић, Марковић 2000: Н. Богдановић, Ј. Марковић, Практикум из дијалектологије, Ниш: Филозофски факултет.

Буци, Бакстер 1984: W. Bucci, M. Baxter, Problems of Linguistics Insecurity in Multicultural Speech Contexts, u: Annals of the New York Academy of Sciences, Vol. 433, 185-200.

Гарет и др. 2011: P. Garrett, C. Selleck, N. Coupland, English in England and Wales: Multiple ideologies, u: Standard Languages and Language Standards in a Changing Europe, Oslo: Novus Press, 57-65.

Јанда 1978: Janda D. Richard, Hypercorrect-ion and Hyper-correction in Phonological Change, Edmonton: Linguistics Research.

Јањић 2004: М. Јањић, Настава падежа у школама на подручју призренскотимочког дијалекта, Кюижевност и језик LI, 3-4, 407-423.

Јањић 2005: М. Јањић, Настава падежа у теорији и пракси, Врање: Учитељски факултет.

Јањић 2008: М. Јањић, Савремена настава говорне културе у основној школи, Нови Сад: Змај.

Карли и др. 2003: A. Carli, C. Guardino, M. Kaučić-Baša, E. Sussi, M. Tessarolo, M. Ussai, Asserting ethnic identity and power through language, u: Journal of Ethnic and Migration Studies, vol. 29, no. 5: 865-883.

Кожух, Максимовић 2013: В. Kožuh, J. Maksimović, Upotreba PSPP programa u pedagoškim istraživanjima, Niš: Filozofski fakultet.

Лабов 1966: W. Labov, The Social Stratification of English in New York City, Arlington, VA: Center for Applied Linguistics.

Лабов 1972: W. Labov, Language in the inner city: Studies in the Black English vernacular, Philadelphia: University of Pennsylvania Press.

Лабов 1994: W. Labov, Principles of Linguistics Change: Internal Factors, Oxford: Blackwell.

Мари 1996: R. Murray, Historical linguistics: the study of language change, Contemporary Linguistics, 313-371.

Милрој 2001: J. Milroy, Language ideologies and the consequences of standardization, u: Journal of Sociolinguistics, 5/4, 530-555.

Николић 1999: М. Николић, Методика наставе српског језика и књижевности, Београд: ЗУНС.

Пауновић, Лопичић 2008: T. Paunović, V. Lopičić, U potrazi za (jezickim) identitetom, u: Srpski jezik-studije srpske i slovenske, 13 (1-2), 365-383. 
Палант 2007: P. Džuli, SPSS: priručnik za preživljavanje, Beograd: Mikro knjiga.

Рајић 1981: Љ. Рајић, Положај корисника дијалекта у процесу стандардизације говора, Книжевност и језик, XXVIII/3-4, 243-248.

Станковић 2016: Б. Станковић, Корелација професије и хиперкорекције код говорника српског језика, у: Годишґак за српски језик, година XXVII, бр. 14, Ниш: Филозофски факултет, 227-244.

Трашил 2003: P. Trudgill, A Glossary of Sociolinguistics, Edinburgh: Edinburgh University Press.

\author{
Aleksandar M. Novaković \\ HYPERCORRECTION IN SPEECH OF PUPILS AND STUDENTS \\ IN THE AREA OF PRIZREN-TIMOK DIALECT
}

Summary

The paper examines the phenomena of hypercorrection in speech of primary and secondary school pupils as well as students who do not attend Philological Faculty. A survey conducted in December 2015 fully confirmed the initial hypothesis that the tendency towards hypercorrection will grow going towards final grades (years) of higher levels of school (college) education in accordance with the change of the number of Serbian language classes which pupils (students) have in their schools (colleges). The connection between hypercorrection and the stages of education (level of education) and the number of Serbian language classes which in the period of four years had primary and secondary school pupils and university students is established with the help of software package SPSS 20.0. On a sample of 305 respondents, the highest propensity towards hypercorrection was shown by the fourth year students who do not attend Philological Faculty, slightly lower propensity was shown by the fourth grade grammar school pupils and minimum propensity was shown by the eighth grade elementary school pupils. Expressed as a percentage, $90.1 \%$ of students, $79.8 \%$ of high school pupils and $71 \%$ of primary school pupils has made some kind of Hypercorrection.

Key words: hypercorrection, Prizren-Timok dialect, Serbian language teaching, language insecurity, prestige language. 